\title{
Introduction to the GaLA Conf 2018 Special Issue
}

\author{
Pedro A. Santos ${ }^{1}$, Remco Veltkamp ${ }^{2}$, João Dias ${ }^{1}$ \\ ${ }^{1}$ Instituto Superior Técnico / INESC-ID, Universidade de Lisboa, \\ pedro.santos@tecnico.ulisboa.pt and joao.dias@gaips.inesc-id.pt \\ ${ }^{2}$ Utrecht University, R.C.Veltkamp@uu.nl
}

We are very pleased to introduce this special issue of IJSG, which is dedicated to the Games and Learning Alliance Conference (GaLA Conf), that was held in Lisbon, December 5-7, 2017. Around 50 participants converged in this beautiful city for a lively workshop and for sharing knowledge and experiences related to serious games, their techniques and application. A number of the best conference papers were selected, and the authors were invited to extend their paper with at least one third new content, and to submit their paper to IJSG with a regular review process. This issue contains four of these papers plus a tutorial on machine learning for interactive pedagogical systems.

The first paper, from Darina Dicheva, Keith Irwin and Christo Dichev is titled "OneUp: Supporting Practical and Experimental Gamification of Learning" [1]. The paper describes a customizable platform aimed at facilitating the process of gamifying academic courses and enabling contextual studies on educational gamification.

The second paper is "Visuospatial Abilities Training with Digital Games in a Primary School", by Laura Freina and Rosa Bottino [2]. The paper presents the results of an interesting study showing a statistically significant improvement of certain mathematical skills in an experimental group of students using digital games, when compared to a control group, for nearly all the indicators considered.

The third paper, by Heiko Holz, Katharina Brandelik, Benedikt Beuttler, Jochen Brandelik and Manuel Ninaus, is titled "How to train your syllable stress awareness" [3]. This paper presents the state of research regarding developmental dyslexia with the German population and a mobile serious game that uses evidence-based trainings and introduces novel features in order to help dyslexic children. They also propose an intervention to train awareness of syllable stress and explore the innovative use of mouth motor activities and embodied trainings, using the game. Finally, the authors present the results of a pilot study.

The fourth paper is "Get Gamification of MOOC right!" by Alessandra Antonaci and Roland Klemke [4]. This paper presents a theoretical framework for the gamification design process and the quantitative and qualitative results of a study to identify the most suitable game elements to use. The findings enable designers of gamification and MOOCs to see these two phenomena under a new light.

The last paper is an invited written version of a workshop from the conference's first day, which raised much interest: "A tutorial on machine learning for pedagogical systems", by Francisco S Melo, Samuel Mascarenhas and Ana Paiva [5] provides a short introduction to the field of machine learning for interactive pedagogical systems. Departing from different examples encountered in those systems - such as intelligent tutoring systems or serious games -it goes over several representative families of methods in machine learning, introducing at the same time key concepts from this field.

Finally, we would like to invite you to participate in the next GaLA Conference, which will take place 5-7 December 2018 in Palermo (https://conf.seriousgamessociety.org/). It will be a great opportunity to share knowledge, opinions and ideas. Again, the conference offers various tutorials targeted to broaden and deepen knowledge of (young) researchers. The conference will also include an exhibition, where developers can showcase their latest products. We hope to meet you all at the GaLA Conference.

Pedro A. Santos

Remco Veltkamp

João Dias 


\section{References}

[1] Dicheva, D., Irwin, K., and Dichev, C. "OneUp: Supporting Practical and Experimental Gamification of Learning", The Int'l Journal of Serious Games, Vol.5, Nr.3, September 2018. http://dx.doi.org/10.17083/ijsg.v5i3.236

[2] Freina, L., and Bottino, R., "Visuospatial Abilities Training with Digital Games in a Primary School", The Int'l Journal of Serious Games, Vol.5, Nr.3, September 2018 http://dx.doi.org/10.17083/ijsg.v5i3.240

[3] Holz, H., Brandelik, K., Beuttler, B., Brandelik, J., and Ninaus, N., "How to train your syllable stress awareness - A digital game-based intervention for German dyslexic children", The Int'1 Journal of Serious Games, Vol.5, Nr.3, September 2018. http://dx.doi.org/ http://dx.doi.org/10.17083/ijsg.v5i3.242

[4] Antonaci, A., and Klemke, K., "Get Gamification of MOOC right! How to Embed the Individual and Social Aspects of MOOCs in Gamification Design", The Int'l Journal of Serious Games, Vol.5, Nr.3, September 2018 http://dx.doi.org/10.17083/ijsg.v5i3.255

[5] Melo, F. S., Mascarenhas, S., and Paiva, A., "A tutorial on machine learning for interactive pedagogical systems", The Int'l Journal of Serious Games, Vol.5, Nr.3, September 2018. http://dx.doi.org/10.17083/ijsg.v5i3.256 